\title{
Mekteb-i Harbiye Nazırlarından Matematikçi Mehmed Emin Paşa’nın Biyografisine Giriş
}

\section{An Introduction to the Biography of Mehmed Emin Pasha, a Mathematician and Director of the Military Academy, Istanbul}

\author{
Atilla Polat ${ }^{1}$ (i)
}

'Arş. Gör., İstanbul Üniversitesi, Edebiyat Fakültesi, Bilim Tarihi Bölümü, İstanbul, Türkiye

\section{ORCID: A.P. 0000-0002-4300-4381}

Sorumlu yazar/Corresponding author: Atilla Polat,

İstanbul Üniversitesi, Edebiyat Fakültesi, Bilim Tarihi Bölümü, İstanbul, Türkiye

E-mail/E-posta: atilla.polat@istanbul.edu.tr

Başvuru/Submitted: 16.04.2019 Revizyon Talebi/Revision Requested: 25.04.2019

Son Revizyon/Last Revision Received:

30.04.2019

Kabul/Accepted: 02.05 .2019

Online Yayın/Published Online: 03.07.2019

\section{Atıf/Citation:}

Polat, Atilla. "Mekteb-i Harbiye Nazırlarından Matematikçi Mehmed Emin Paşa'nın

Biyografisine Giriş̧." Osmanlı Bilimi Araştırmaları 20, 2 (2019): 59-74.

https://doi.org/10.26650/oba.554557

\section{öz}

Mehmed Emin [Paşa], 1251 (1835) senesinde tahsil için İngiltere'ye gönderilen subaylardandır. Cambridge'de matematik eğitimi almış ve Cambridge Üniversitesi'nden mezun olduktan sonra, varyasyon hesabı (hisab-ı tebeddülat) üzerine İngilizce olarak kısa bir çalışma hazırlamıştır. Füzeler üzerine olan bir çalışmasını ise Fransa'da bastırmıştır. Yurda döndüğünde Mekteb-i Harbiye Nazırı olarak 1841-1846 yıllarında görev yapan Mehmed Emin Paşa 1851'de kurulan Encümen-i Dâniş̧in de üyelerindendir. Bu çalışmada Mehmed Emin Paşa hakkında yeni bulunan bilgiler verilecek ve bunun yanında Mehmed Esad ve Salih Zeki'nin onun hakkında yazdıkları biyografilerin Latin harflerine çevirileri okuyucuya sunulacaktır.

Anahtar sözcükler: Mehmed Emin Paşa, Mekteb-i Harbiye, Hisab-ı Tebeddülat, Varyasyonlar Hesabı, Cambridge Üniversitesi

\section{ABSTRACT}

Mehmed Emin [Pasha] was among those young Turkish officers who were sent to England to receive military education in 1835 . Besides being trained in the military arts, he studied mathematics at Cambridge University. Following his graduation from the university, he compiled a treatise titled An Introduction to the Calculus of Variations. He also published in France a study on the mathematical principles of missiles under the title Mémoire sur un nouveau système de confection des fusées de guerre. On his return to Turkey he was appointed director of the Turkish Military Academy (1841-1846). He was also a member of the Ottoman Academy of Sciences (Encümen-i Dâniş), established in 1851 . The present article aims to provide newly disclosed biographical information about Mehmed Emin Pasha and to give the transliterations of his two previous biographies in Ottoman Turkish, written by Mehmed Esad and Salih Zeki.

Keywords: Mehmed Emin Pasha, Mekteb-i Harbiye, Calculus of Variations, Cambridge University 


\section{Giriş}

Devlet adına 1251/1835 senesinde eğitim için İngiltere'ye gönderilen subay ve öğrenciler arasında bulunan ${ }^{1}$ ve eğitiminin ardından yurda döndüğünde Mekteb-i Harbiye nazırlığı yapan Mehmet Emin Paşa (ö. 1267/1851) kısa süren yaşamında bilim ve eğitim tarihimiz açısından önemli faaliyetlerde bulunmuştur. Mehmed Esad ve ondan nakille Salih Zeki, babasının Mühendishane başhocalarından Hüseyin Rıfkı (Tamani) olduğunu söylemektedir. ${ }^{2}$ Hüseyin Rıfkı Efendi'nin vefatının ardından geride kalan ailesine maaş verilmesiyle ilgili bir belgede tek erkek çocuğunun ismi Mehmed Emin olarak görülür. Mehmed Emin Paşa'nın annesi ise Havva Hanım'dır. ${ }^{3}$ Züleyha Hanım ile evlenmiş olan Mehmed Emin Paşa'nın bir kızı vardır. ${ }^{4}$ Kendisinin İngiltere'ye gönderilmeden önceki hayatıyla ilgili bildiklerimiz şimdilik Mühendishane'ye devam etmesi ve buradaki eğitiminin ardından istihkâm alayında alay emini olarak görevlendirilmesiyle sınırlıdır. Bu çalışma süresince Mehmed Emin Paşa'dan bahseden kaynaklar tespit edilerek gözden geçirilmiştir. Bu kaynaklar Mehmed Esad'ın 1310/1894 yılında yayımlanan Mirat-ı Mekteb-i Harbiye'si ve Salih Zeki'nin (basılı olmayan) Kamus-ı Riyaziyat metnidir. ${ }^{5}$ Salih Zeki, Emin Paşa'nın terceme-i halini yazarken Mehmed Esad'ın eserinden faydalanmış ve bunu belirtmişstir. Mehmed Esad, Emin Paşa'nın Mekteb-i Harbiye'nin başında bulunduğu dönemi ayrıntısıyla anlatırken, Salih Zeki bu kısmı tekrar vermeye lüzum görmemiştir. Salih Zeki'nin Emin Paşa maddesindeki önemli bilgilerden biri, Emin Paşa'nın iki çalışması için Vidinli Hüseyin Tevfik Paşa'nın (1832-1901) ${ }^{6}$ yazdığı kısa değerlendirmedir. Çalışmamızın ekinde günümüz harflerine aktararak vereceğimiz Salih Zeki ve Mehmed Esad'ın yazdıklarının yanında Sicill-i Osmani'de de kısa bir Emin Paşa maddesi vardır. ${ }^{7}$ Emin Paşa'nın hayatı hakkındaki biyo-bibliyografik kaynaklardan biri Osmanlı Matematik Literatürü olmasına rağmen buradaki bilgiler Mehmed Esad ve

11250 ve 1251 senelerinde Mühendishane'den ve Mekteb-i Harbiye'den tahsil için İngiltere'ye gönderilen zabit ve talebeler şunlardır: İstihkam kaymakamı Bekir Bey, İstihkam alay emini Emin Bey, İbrahim Efendi, Derviş Efendi, Yusuf Efendi, Süleyman Efendi, Mahmud Efendi, Tahir Efendi, Arif Efendi, Ahmed Efendi, Halil Efendi. Bu isimlerin yurtdışından döndüklerinde Tophane-i Amire ve ona bağlı Baruthane, Fişenkhane, Dökümhane ve diğer çeşitli fabrikalar ile Mekteb-i Harbiye-i Şahane'de başta muallimlik olmak üzere çeşitli vazifeler almaları amaçlanmıştı. Bkz. Mehmed Esad, Mirat-ı Mühendishane-i Berri-i Hümayun (İstanbul Teknik Üniversitesi Tarihçesi), ed. Sadık Erdem (İstanbul: İTÜ Bilim ve Teknoloji Tarihi Araştırma Merkezi, 1986), 51-52; Yine Mehmed Esad'in Mirat-l Mekteb-i Harbiye'sinde Humbarahane'den Alay Emini Emin Bey'in 1251 senesinde Mekteb-i Harbiye'den Londra'ya tahsile gidenler arasında olduğu görülmektedir. Bkz. Mehmed Esad, Mirat-ı Mekteb-i Harbiye (İstanbul: Şirket-i Mürettibiye Matbaası, 1310), 19.

2 Mehmed Esad, Mekteb-i Harbiye, 33; Salih Zeki, "Kamus-1 Riyaziyat," İstanbul, İstanbul Üniversitesi Nadir Eserler Kütüphanesi, T910, 539.

3 Başbakanlık Osmanlı Arşivi (BOA), Cevdet Maarif (C. MF) 43/2150, 7 Cemaziyelahir 1232 (24 Nisan 1817).

4 BOA, İrade Dahiliye (İ. DH) 237/14320, 22 Ramazan 1267 (21 Temmuz 1851); BOA, İ. DH 245/14911, 24 Safer 1268 (19 Aralık 1851).

5 Mehmed Esad, Mekteb-i Harbiye, 32-43. Salih Zeki, "Kamus," 539-542.

6 Atilla Polat, "Son Dönem Osmanlı Matematikçi-Bürokratı Vidinli Hüseyin Tevfik Paşa'nın Hayatı," Osmanlı Bilimi Araştırmaları 20,1 (2019): 16-41.

7 Mehmed Süreyya, Sicill-i Osmani, c. 2, ed. Nuri Akbayar (İstanbul: Tarih Vakfı Yurt Yayınları, 1996), 478. 
Salih Zeki'nin verdikleri bilgilerden derlenmiştir. ${ }^{8}$ Osmanlı Matematik Literatürü’nde Emin Paşa'nın telifi olan iki eserden bahsedilmekte ancak bu eserlerin kopyalarının bulunduğu bilgisi yer almamaktadır. Yaşamları ve Yapıtlarıyla Osmanlılar Ansiklopedisi'nde bulunan Emin Paşa maddesi de önceki çalışmaları tekrar eder. ${ }^{9}$

$\mathrm{Bu}$ çalışma sürecinde kendisine atfedilen fakat şimdiye kadar bulunamamış olan iki eseri tespit edilmiş, bunun yanında İngiltere'de kaldığı süre içerisinde matematik dergilerine soru-cevaplar ile katkıda bulunduğu da belirlenmiştir. ${ }^{10} \mathrm{Bu}$ araştırmada Emin Paşa hakkında şimdiye kadar tespit edilen malzeme ortaya konulacaktır. Başbakanlık Osmanlı Arşivi'nde yapılacak daha ayrıntılı bir araştırma ve iki eserinin bilim tarihi açısından değerlendirilmesini içeren bir makale ise ileriki dönemde hazırlanacaktır.

\section{İngiltere Dönemi (1835-1840)}

Emin Paşa'nın hayatını ilginç kılan noktalardan biri Cambridge'de matematik eğitimi almış olmasıdır. Çünkü kendisinin ve yurtdışına gönderilen diğer öğrenci ve subayların matematik eğitimi almalarının istendiğini gösteren bir belge henüz ortaya konmamıştır. Hatta kendisi, İngiltere'ye muhtemelen maden yataklarını belirleme, çıkarma ve maden döküm tekniklerini öğrenmek için gönderilmişti. ${ }^{11}$ İngiltere'deki ilk yıllarında, yani Cambridge'de matematik eğitimi almaya başlamadan önce, İngilizcesini ilerletmiş ve ardından bir süre muhtemelen Woolwich kasabasında bulunan Kraliyet Askerî Akademisi'ne devam etmiştir. ${ }^{12}$ 1837'de ise Cambridge Üniversite'ne geçtiği ve devamında eğitimini burada sürdürdüğü

8 Ekmeleddin İhsanoğlu, Ramazan Şeşen, ve Cevat İzgi, Osmanlı Matematik Literatürü Tarihi, c. 1, ed. Ekmeleddin İhsanoğlu (İstanbul: İslâm Tarih, Sanat ve Kültür Araştırma Merkezi IRCICA, 1999), $296-298$.

9 Salim Aydüz. "Emin Paşa," Yaşamları ve Yapıtlarlyla Osmanlılar Ansiklopedisi, cilt 1 (İstanbul: Yapı Kredi Kültür Sanat Yayınları, 2008), 401.

10 Emin Paşa'nın 1839 tarihli matematik eserinin (An Introduction to the Calculus of Variations with a Theoretical View of Maxima and Minima) kopyası İTÜ Kütüphanesi’nden (no: QA315 .A44 1839); 1840 tarihli diğer eserinin (Mémoire sur un nouveau système de confection des fusées de guerre) kopyası ise Fransa Milli Kütüphanesi'nden (no: VP-5668) temin edilmiştir. Bahse konu dergiler ise Ladies' Diary ve Lady's and Gentleman's Diary'dir.

11 Ahmet Dönmez, “Osmanl-İngiliz İlişkileri: Diplomasi ve Reform (1833-1841)” (Yayımlanmamış Doktora Tezi, Selçuk Üniversitesi, 2013), 178.

12 Ahmet Dönmez'in çalışması incelendiğinde İngiltere'deki sürecin oldukça karışık ve zorlu olduğu, öğrenci ve subaylarımızın öğrenim süreçlerinin aksaklıklara uğradığı anlaşılmaktadır. Ayrıca Woolwich'e devam etme konusu da bazı belirsizlikler içermektedir. Bkz. Dönmez, "Osmanlı-İngiliz İlişkileri," 169-188. Emin Paşa'nın da içinde bulunduğu gruptaki öğrencilerden olan Arif Efendi’nin vefatı ve Woolwich’teki kabri ile ilgili bir makale için bkz. Henry George Farmer, “A Turkish Officer's Tomb at Woolwich,” Oriens 8, 1 (1955): 94-95. Emin Paşa'nın babası olan mühendishane başhocalarından Hüseyin Rıfkı Tamani'nin (ö. 1232/1817) Usul-i Hendese tercümesine esas aldığı Elementler versiyonu John Bonnycastle'ınkidir (1751-1821). Bonnycastle, Woolwich akademisinde ders vermiştir. Ayrıca Emin Paşa'nın İngiltere'de iken takip ettiği matematik dergisi Ladies' Diary de Woolwich Akademisi’yle ilişkilidir. Bkz. Joe Albree, ve Scott H. Brown, "A Valuable Monument of Mathematical Genius: The Ladies' Diary (1704-1840),” Historia Mathematica 36, 1 (2009): 11. 
görülmektedir. ${ }^{13}$ Kayıtlarda isminin "Mohammed Zeki Ameen Bey" veya "Amun Bey" olarak geçmesi, Emin Paşa’nın buradaki varlığının ve çalışmalarının araştırmacılarca fark edilmemesine neden olmuş olabilir. Kendisinin İngiltere'de nasıl bir sosyal çevreye dâhil olduğu ve nasıl vakit geçirdiği şimdilik bilinmemekle birlikte, zamanının önemli bir bölümünü matematiğe ayırdığı düşünülür. Popüler bir matematik dergisine gönderdiği soru-cevaplar, Cambridge'den mezuniyeti için hazırlamış olduğu varyasyon hesabı ile ilgili matematik çalışması ve 1840'ta Fransa'da bastırdı̆̆ı roketlerin matematiksel prensiplerini ele alan eseri, bu duruma delil olarak gösterilebilir. ${ }^{14}$ Emin Paşa, An Introduction to the Calculus of Variations adlı eserine yazdığı önsözde Cambridge'de bulunmanın kendisine yaptığı katkılarından bahseder. Üniversiteye üye olarak kabul edilmesinden duyduğu şerefi, kendisine gösterilen misafirperverliği edebi bir biçimde ifade eder. Kendi ifadeleriyle "berrak bir bilgi pınarından yudumlamasına izin verilen bir kişi”"dir. "Newton'un adımlarını izlemesine müsaade edilen” Emin Paşa, "Britanya'nın asil evladından” pek çok şey öğrenmiştir. Önsözün bütününe bakıldığında Emin Paşa'nın bilime ve bilmeye olan merakının İngiltere'de bulunduğu yıllarda pekiştiği söylenebilir. ${ }^{15}$

Emin Paşa hakkında çeşitli yabancı kaynaklarda rastladığımız bilgiler de İngiltere'de geçirdiği yıllar hakkında bir fikir vermektedir. Dönemin meşhur matematikçilerinden Augustus de Morgan (1806-1871) bir eserinde, Emin Paşa ve babası Hüseyin Rıfkı'dan kısaca bahsetmekte ve Emin Paşa'nın İngiltere'de bulunduğu yıllarda cana yakın, kültürlü bir beyefendi ve çok iyi bir matematikçi olarak tanındığını belirtmektedir. ${ }^{16}$ Bunun yanında,

13 Cambridge Üniversitesi mezunları veritabanında, Emin Paşa'nın 23 Ekim 1837 tarihinde Trinity Hall'a “fellow commoner"olarakkabuledildiğibilgisiverilmektedir,bkz. “CambridgeÜniversitesiMezunAramaSayfas1,"erişim 05 Mart 2019, http:/venn.lib.cam.ac.uk/cgi-bin/search-2018.pl?sur $=\&$ suro $=w \&$ fir $=\&$ firo $=\mathrm{c} \& \mathrm{cit}=\& \mathrm{cito}=\mathrm{c} \& \mathrm{c}=$ all\&z=all\&tex $=$ ameen $\&$ sye $=\&$ eye $=1839 \& \mathrm{col}=$ all $\&$ maxcount $=50$. Buradaki Trinity Hall, Trinity College ile karıştırılmamalıdır. Ayrıca Emin Paşa’nın adının geçtiği şu eserlere de bakılabilir: John Venn, ve John Archibald Venn, ed. Alumni Cantabrigienses: A Biographical List of All Known Students Graduates and Holders of Office at the University of Cambridge, From the Earliest Times to 1900, Volume 2: From 1752 to 1900, Part 1: Abbey-Challis, c. 2 (Cambridge: Cambridge University Press, 2011), 49; Joseph Romilly, Romilly's Cambridge Diary, 1832-1842 (Cambridge: Cambridge University Press, 1967), 238. Fellow commoner, genellikle zengin ailelerden gelen lisans seviyesindeki öğrencilere verilen bir sıfattır. Bu öğrenciler, üniversite öğretim üyeleriyle aynı masada yemek yeme ayrıcalığına sahiptir. Detaylı bilgi için bkz. "The Jargon," erişim 05 Mart 2019, http://www.queens.cam.ac.uk/life-at-queens/about-the-college/university/the-jargon.

14 Emin Paşa'nın Ladies'Diary ve Lady's and Gentleman's Diary dergilerine gönderdiği soru ve çözümlerin yer aldığ 1 sayfalar için bkz. The Ladies 'Diary (London: The Company of Stationers) (1839): 51-52. The Ladies' Diary (London: The Company of Stationers) (1840): 33-36, 38, 40-44, 47-48. The Lady's and Gentleman's Diary (London: The Company of Stationers) (1841): 42, 50, 63. Kendisinin mezuniyeti sebebiyle hazırladığ1 çalışması için bkz. Colonel M. Z. Ameen Bey, An Introduction to the Calculus of Variations with a Theoretical View of Maxima and Minima (Cambridge: Metcalfe and Palmer, 1839). Fransa'da basılan eseri için bkz. Emin Pacha, Mémoire sur un nouveau système de confection des fusées de guerre (Paris: Bachelier, 1840). Osmanlı Askerlik Literatürü'nden öğrendiğimize göre Emin Paşa'nın roketlerle ilgili bu eseri Mehmed Sadık Efendi (ö. 1302/1885) tarafından Türkçe'ye çevrilmiştir. Bkz. Ekmeleddin İhsanoğlu, Ramazan Şeşen, M. Serdar Bekar, ve Gülcan Gündüz. Osmanlı Askerlik Literatürü Tarihi, c.1, ed. Ekmeleddin İhsanoğlu (İstanbul: İslâm Tarih, Sanat ve Kültür Araştırma Merkezi IRCICA, 2004), 129-130.

15 Ameen Bey, Calculus of Variations, i-ii.

16 Augustus de Morgan, A Budget of Paradoxes (London: Longmans, Green, 1872), 258; Sophia Elizabeth de Morgan, Memoir of Augustus de Morgan (London: Longmans, Green, 1882), 335. 
Cambridge Üniversitesi’nde yöneticilik yapmış olan Joseph Romilly (1791-1864) günlüğünde, bir davette Emin Paşa'ya satranç oynamayı teklif ettiğinden ve aralarındaki kısa diyalogdan bahsetmekte ve Emin Paşa'yı bir "Türk" ve "matematikçi” olarak tanımlamaktadır. ${ }^{17}$ Emin Paşa'nın temas içerisinde olduğu (veya temas kurmaya çalıştığı) isimlerden birinin matematikçi Augustin-Louis Cauchy (1789-1857) olduğunu düşünüyoruz. Cambridge'de bulunduğu sırada hazırlamış olduğu An Introduction to the Calculus of Variations adlı çalışmasının bir nüshasını imzalı olarak Cauchy’ye göndermiş olması böyle bir bağlantıyı kurmamıza imkân sağlamaktadır. ${ }^{18}$ Bunun yanında, dönemin popüler süreli matematik yayınları The Ladies' Diary ve The Lady's and Gentleman's Diary'ye göndermiş olduğu soru-cevaplar vesilesiyle, Emin Paşa'nın matematikçiler topluluğu içinde bir yer edinmeye gayret ettiğini düşünüyoruz. Meşhur İskoç seyyah Charles Mac Farlane'in (1799-1858) hatıralarında da Emin Paşa ile ilgili bir bölüm bulunmaktadır. İngiltere'ye geldiğinde maddi olarak hiçbir şeyi olmayan ve hiç tanınmayan Emin Paşa, Mac Farlane’e göre o dönemlerde “çulsuz bir şeytan”dır (un pauvre diable). Mac Farlane, Emin Paşa'nın özellikle matematikteki kabiliyeti nedeniyle oldukça dikkat çektiğini ve misafirperverlik gördüğünü eklemektedir. ${ }^{19}$

Emin Paşa, İngiltere'de bulunduğu süre içerisinde Dersaadet ile irtibatını devam ettirmiştir. Mühendishanedeki dostlarıyla mektuplaşmış ve bu mektuplarda matematikten bahsedilmiştir. ${ }^{20}$ İstanbul'a döndükten sonra da tespit edebildiğimiz kadarıyla 1831'de kurulmuş olan British Association for the Advancement of Science'ın 1846 y1lında Southampton'da on altıncısı düzenlenen yıllık toplantısına katılmıştır. ${ }^{21}$ Bu katılımın öncesi ve sonrasıyla ilgili bilgilere henüz sahip değiliz.

Emin Paşa 1840 yılına kadar İngiltere'de kalmıştır. Emin Paşa'nın İngiltere'den ayrılışı 12 Aralık 1840 tarihli The Cambridge Chronicle' da da yer bulmuştur:22

Emir [sic] Pacha, late of Trinity hall, Cambridge, the celebrated Turkish mathematician, has returned to Constantinople from Europe, where he has spent more than five years in the acquisition of science; it is spoken of as being probable that he will be appointed minister of public instruction, or a director of a polytechnic school.

17 Romilly, Romilly's Cambridge Diary, 150.

18 Cambridge'deki St. John College Kütüphanesi’nde Emin Paşa'nın kitabının bir kopyası bulunmaktadır. Kütüphanenin dijital kataloğunda verilen bilgiye göre (temellük kaydı) eser Cauchy’ye imzalanmıştır. İlk sahibi olan Cauchy'den sonra eser, St John's College'da da görev yapmış olan matematikçi Isaac Todhunter'a (18201884) ve ondan da eşi Louisa Anne Maria Todhunter'a geçmiştir. Son olarak eser, Maria Todhunter tarafindan kütüphaneye bağışlanmıştır, bkz. "Emin Paşa'nın matematik kitabının St. John’s Koleji Kütüphanesi'ndeki kopyası," erişim 05 Mart 2019, http://idiscover.lib.cam.ac.uk/primo-explore/fulldisplay?docid=44CAM_ALMA 214177669 60003606\&context=L\&vid=44CAM_PROD\&search_scope=default_scope\&tab=default_tab\&lang=en_US.

19 Charles Mac Farlane, Turkey and its Destiny: The Results of Journeys Made in 1847 and 1848 to Examine into the State of that Country, c. 2 (London: John Murray, 1850), 153-160.

20 Salih Zeki, "Kamus," 539.

21 W. H. Bidwell (ed.), The Eclectic Magazine of Foreign Literature, Science, and Art, c. 22 (New York: Leavitt, Trow, \& Co., 1851), 158.

22 The Cambridge Chronicle and Journal, and Huntingdoneshire Gazette, 12 Aralık 1840, 2. 
İngiltere'den ayrıldıktan sonra bir süre Paris’te kalan Emin Paşa, Fransızca hazırladığ 1840 tarihli kitabını Paris’te kaldığı dönemde yayımlamış olmalıdır. Emin Paşa, Fransa'dan İstanbul'a gönderdiği bir izin talebinde Fransa'da da İngiltere'deki gibi ciddi bir şekilde çalıştığından, fakat tatil döneminin başlaması sebebiyle sadece Fransızca çalışabileceğinden bahsetmektedir. Henüz Fransızcası istediği seviyeye gelmeyen Emin Paşa, buna mukabil bilim kitaplarını kolaylıkla anlayabilmektedir. Fransızcasını yurda döndükten sonra da ilerletebileceğini düşünen Emin Paşa'nın istediği izin, Fransa'dan ayrılmasının akabinde önce Berlin'e ve ardından da Viyana'ya bir buçuk veya ikişer aylığına uğrayarak buralardaki askerî okulları, tophaneleri ziyaret ederek yeni icatları görmek ve incelemek içindir. ${ }^{23}$ Emin Paşa'nın dönüş yolunda (Viyana'da) harcırahının yetmediğini gösteren bir belge de arşiv kayıtlarında bulunmaktadır. Söz konusu belgeye göre kendisinin 1840’ın sonlarında yurda döndüğü anlaşılmaktadır. ${ }^{24}$

\section{İstanbul'a Dönüş ve Yeni Görevleri (1840 - 1851)}

Yurda dönen Emin Paşa mirlivalık rütbesine getirilmiş ve 1257/1841'de Mekteb-i Fünun-1 Harbiye Nazırlığına tayin olunmuştur. ${ }^{25}$ Mirat- $\iota$ Mekteb-i Harbiye ve Kamus- $\iota$ Riyaziyat'ta bu tayinin Emin Paşa'nın gayret ve çalışkanlığının bir takdiri olduğu "Kabiliyettir husul-i matlabın sermayesi, elde istidat olunca kâr kendin gösterir" sözleriyle ifade edilmiştir. ${ }^{26}$ Buradaki görevi süresince Emin Paşa, Mekteb'in daha iyi bir noktaya gelebilmesi için Mekteb-i Fünun-1 Harbiye'ye öğrenci yetiştirmek için Mekâtib-i İdadiye'nin açılmasına gayret etmiştir. Emin Paşa, okulun Mekteb-i Ulum-1 Harbiye ve Mekteb-i Fünun-1 İdadiye olarak iki kısma ayrılması, yeni programların hazırlanması, derslerin sayısı ve eğitim süresinin belirlenmesi, görev yapacak hocaların temini, binaların inşası, derslerde kullanılacak bilimsel aletlerin tedariki gibi hususlarla bizzat ilgilenmiştir. Tüm bunların yanında sadece bir yönetici olmakla kalmamış, bizzat Mekteb-i Harbiye'deki eğitim faaliyetine de katkıda bulunmuştur. Son sınıflardan seçtiği yirmi dört zeki öğrenciye kendi odasında cebir dersi vermesi ve öğrencilerdeki gelişmeyi de takip etmesi bu noktada önemli bir örnektir. Emin Paşa, Mekteb-i Harbiye Nazırlığı'nın dışında başka vazifeleri de üstlenmiştir. Kendisini 1261(1845) senesinde bir süre Dar-1 Şura-yı Askeri’de aza olarak görüyoruz. Bu sırada, Cebel-i Lübnan'da çıkan karışıklıklar üzerine bölgeye gönderilmiştir. İstanbul'a dönüşü sonrası 1262 (1845-46) senesinde feriklik rütbesiyle birlikte Rumeli Ordusu Riyaseti'ne getirilmiştir. Bu vazifesinde, Arnavutluk civarındaki meşhur eşkıyalar ile uğraşmış, yaklaşık bir senedir Devlet'i uğraştıran bu çeteyi dağıtmıştır. Göstermiş olduğu

23 BOA, İrade Hariciye (İ. HR) 5/249, 29 Rebiülahir 1256 (30 Haziran 1840).

24 BOA, İ. HR 7/352, 7 Ramazan 1256 (2 Kasim 1840).

25 Salih Zeki, Kamus, 539; Mehmed Esad, Mekteb-i Harbiye, 32; Mehmed Süreyya, Sicill-i Osmani, 478. Ancak Başbakanlık Osmanlı Arşivi'de bulunan bir belgede Emin Paşa'nın mirlivalığa henüz İngiltere iken getirildiğini yazmaktadır. Bkz. BOA, Hatt-1 Hümayun (HAT) 309/18272, 29 Zilhicce 1253 (26 Mart 1838). 
askeri başarıya mükâfat olarak 1263 (1846-47) senesinde Dar-1 Şura-yı Askeri'nin başına getirilmiştir. Ardından, Rumeli Ordusu Müşiri olarak görevlendirilmiş, ancak bu görevine başlamadan Arabistan Ordusu Müşirliği'ne tayin edilerek Şam'a gönderilmiştir. Arabistan civarında, daha önceleri askere alımlarda ortaya çıkan karışıklıklara son verme amacıyla kura usulünü ilk uygulayan Emin Paşa olmuştur. Emin Paşa ayrıca 1851 senesinde faaliyete geçen Encümen-i Dâniş’in dâhili azalarındandır. Ancak, Encümen-i Dâniş'in teşekkülünden yaklaşık üç ay kadar sonra Arabistan Ordusu Müşirliği vazifesiyle Şam'da bulunduğu sırada vefat etmiştir. Şam'da bulunduğu süre boyunca, devlet görevlerinin yanı sıra tasavvufla da meşgul olmuş ve Muhyiddin İbnü'l-Arabî'nin (ö.1240) eserlerini okumuştur. Kabri, İbnü'lArabî’nin türbesi civarındadır. ${ }^{27}$ Emin Paşa'nın vefatından Ceride-i Havadis ve Takvim-i Vakayi'de kısaca bahsedilmiş ve vefat ettiği tarih 16 Zilkade 1267 (12 Eylül 1851) olarak verilmiştir. $^{28}$

\section{Değerlendirme}

Emin Paşa muhtemelen ömrünün kısa sürmesi nedeniyle pek tanınmadan ve çalışmaları da incelenmeden kalmıştır. Bu kısa ömrün kilit noktaları İngiltere’ye gidiş, Cambridge'de matematik tahsili, Mekteb-i Harbiye nazırlığı, Encümen-i Dâniş azalığı ve Arabistan Ordusu Kumandanlığı olarak görülebilir. İngiltere'den tahsilinin ardından Paris, Berlin ve Viyana'da da incelemelerde bulunarak yurda dönen Emin Paşa'nın yurtdışında hazırladıklarının dışında telif veya tercüme bir eserinin olmaması şaşırtıcıdır. Kendisinin iki eserinin bilgisine de Salih Zeki'nin Kamus-ı Riyaziyat'ından ulaşmış ve bu eserleri bulabilmiştik. Emin Paşa'ya ait olan -Salih Zeki'nin belirtmediği- ve henüz ortaya çıkmamış eserlerin olması da imkân dâhilindedir. Ancak, idari ve İstanbul dışı görevlerinin yoğunluğu nedeniyle başka eser hazırlayacak firsat bulamamış olması da pekâlâ mümkündür.

Kamus-l Riyaziyat'tan anladığımız kadarıyla, Emin Paşa'nın eserlerini yine bir matematikçi-asker-bürokrat olan Vidinli Hüseyin Tevfik Paşa değerlendirmiştir. Emin Paşa, Vidinli ve Salih Zeki gibi matematiğe düşkün üç ismin bir şekilde aynı eserde buluşması her ne kadar kaderin hoş bir cilvesi olarak gözükse de, bu durum aslında dönemin mühendislik eğitiminin matematik kültürüne olan ilgiyi geliştirmesinin sonuçlarından biri olarak düşünülebilir. Bu üç ismi, aynı ekolün mensubu olmasalar da, aynı imkân ve imkânsızlıklar çağında aynı çizgide benzer şekilde ilerlemeye gayret eden üç şahsiyet olarak tahayyül etmek sanırız yanlış olmayacaktır.

27 Burada Emin Paşa'nın resmi görevleriyle ilgili verilen bilgiler Mehmed Esad ve Salih Zeki'den derlenmiştir, bkz. Mehmed Esad, Mekteb-i Harbiye, 32-43; Salih Zeki, "Kamus," 539-542. Bu iki kaynakta da bahsedilmeyen bir konu daha vardır, o da Emin Paşa'nın Osmanlı'da uzunluk ölçülerinin standartlaşması için gösterdiği çabadır. Bkz. Feza Günergun, "Eski Fransız ve Osmanlı Ölçü ve Tartılarının Sistemlerindeki Eşdeğerleri: İlk Karşılaştırmalar ve Çevirme Cetvelleri," Osmanlı Bilimi Araştırmaları 2 (1998): 36-39.

28 Ceride-i Havadis, say1 549, 3 Zilhicce 1267, 1; Takvim-i Vakayi, say1 457, 27 Zilhicce 1267, 1. 


\section{EK 1. Mehmed Esad'ın Mirat-ı Mekteb-i Harbiye'sinde (İstanbul 1310, 32-43) yer alan Emin Paşa ile ilgili kısım}

[32] Emin Paşa'nın Nezareti ve İcmal-i Ahvali

1257 Muharreminde Selim Paşa'nın infisalinden sonra Mirlivalık rütbesi ile Emin Paşa Mekteb-i Harbiye'ye nazır tayin olundu. Müşarunileyh Emin Paşa, Mühendishane-i Berri-i Hümayun hocalarından [33] Hüseyin Rıfkı Efendi'nin mahdumu olup Eyüp'te Nizamiye Karakolu karşısında konakları var idi. Hüseyin Rıfkı Efendi, Sultan Selim-i Salis Hazretleri'nin 1210 tarihinde Mühendishane'ye tayin buyurduğu muallimlerden ve ashab-1 fazl u telifatdandır.

Emin Paşa ibtida-yı halinde Mühendishane'ye devam ile oradan neşet edip lağımcı yani şimdiki istihkâm alayına alay emini nasb olunmuşdur. Ve 1250 tarihinde beş nefer-i Mühendishane ve Harbiye talebesi miyanında bera-yı tahsil Londra'ya izam buyurulmuşdur.

Londra'da tahsili esnasında Mühendishanede bulunan ehass-1 rüfekasına cebir ve hendese misalleri gönderip hallini isterdi ve talebe-i mumaileyhim tarafından yazılan cevabın cevabı olarak istifadeli ve fünun-amiz bir surette teati-yi mekâtib edilirdi.

Beyt

Kabiliyetdir husul-i matlabin sermayesi

Elde istidad olunca kâr kendin gösterir

fehvasınca gönderenin terakkiyat-1 fenniye ve tecdidat-1 fikriyesine gereği gibi vakıf olduktan başka buradaki arkadaşlarını dahi ondan müstefid ve haberdar ve binaenaleyh iane ve gayret-i fenniyesiyle mumaileyhimi minnetdar eden Emin Paşa idi.

[34] Müşarunileyh Avrupa'da tahsilini bi'l-ikmal Dersaadet'e gelir gelmez her tarafdan nail-i ihtiram-1 fevkalade olup ol vaktler böyle bir zata muhtac olan Mekteb-i Fünun-1 Harbiye zat-1 maarifsimatlarının Nezaret'e tayinleriyle beraber terakkiyat-1 âtiyesi için bir büyük beşarete ermiş ve tevcih-i vecih-i mezkur hakikaten muvafik-1 maslahat ve ayn-1 isabet olmuşdu. Bir şey ki hüsn-i niyete mukarindir, onda muvaffakiyet mukarrerdir.

Binaenaleyh Emin Paşa dahi terakkiyat-1 fenniye hakkında menvi-i zamiri olan icraata muvaffak olub dinine devletine pek güzel hidmetler ibrazıyla nail-i teveccühat-1 veliyyü'n-nimeye haiz-i ihtiramat-1 umumi olmuşdu. Çünki Mektep Nezareti'ne geldiği zaman Mekteb'in muhtac-1 1slah olduğunu ve istikbalin maarifi için bir esas-1 kavi kurmak icab etdiğini bildiği ve gördüğü cihetle hemen firsatı kaçırmayıp Mekteb'in ıslah ve terakkisine ve şimdiki meşhudumuz olan idadiyelerin tesisine bezl-i ikdam ve gayret ve saye-i Hazret-i Padişahi'de bir hayli asar-1 nafia vücuda getirmeye hasr-1 himmet etmişdir ki bu babdaki izahat zaman-1 nezaretine aid bahisde tafsil edildi.

Mektepde olan vezaifinden başka Mecalis-i Askeriye'ye dahi memur olduğundan barika-i fikr-i maalisinden o vechile Ârâ-yı Askeriye dahi ahz-1 envar-1 istifade etmişdir.

Ezcümle 1259 tarihinde Tensikat-1 Askeriye hakkında Üsküdar'da Muhafız Konağı denilen mahalde müteşekkil meclise aza nasb olunmuş [35] ve 1261'de Dar-1 Şura-yı Askeri'ye memur buyrulmuş ve bir aralık da bera-yı 1slahat Cebel-i Lübnan'a gitmiş gelmişdir. 1263'de Mektep Nezareti'nden bi'linfisal Rütbe-i Samiye-i Müşiri ile Dar-1 Şura-yı Askeri'ye reis tayin buyrulmuşdur, muahharan yine bazı mutena hidematda ibraz-1 gayret ve izhar-1 sadakat ve hasafet eyleyerek nihayet Şam-1 Şerif Valisi iken irtihal-i dar-1 beka eyledi. Muhyiddin-i Arabi hazretlerinin türbe-i münifesi dahilinde medfenârâ-yı ihtiram olmakdadır. Ulum-1 riyaziyeye esasıyla aşina ve akl u fetanetiyle magbutü'l-vüzera bir zat-1 sahib-i zekâ olup lisan-1 Fransevi'de dahi bir telif-i muteberi Fransa üdebasının makbulü olduğu mervidir. 


\section{Müşarunileyhin Eyyam-1 Nezareti}

Bu zat-1 gayret-simat Mekteb'e nazır tayin buyruldukdan biraz müddet sonra Mühendishane hocalarından Büyük Tahir Efendi'yi -Erkan-1 Harbiye Miralayı ve Mektep'de mu'allim iken vefat etmişdir- Mekteb-i Harbiye'ye hisab ve hendese muallimi celb ve tayin ettirdi. Mumaileyh Tahir Efendi sınıfların ileri gelen çavuş ve başçavuşlarına hisabdan beda (بداء) ile hisab-1 adi, küsurat-1 aşariye, tenasüb, logaritma, cüzurat, faiz hisabları gibi ulum-1 riyaziyenin mukaddime ve teferruatını mükemmelen tedris ettirdikden sonra usul-i hendeseye mübaşeret etdirdi. Her ne kadar kendisi fenn-i cebire de aşina ise de [36] pek mükemmel olmadığından ve nazır Emin Paşa'nın ise ulum-1 riyaziyede yed-i tulası bulunduğundan ileriki sınıf ezkiyasından intihab u tefrik ettiği yirmi dört efendiye kendi odalarında müstakilen cebir tedrisine himmet ve hissetdiği terakkiyi ibtida kendi yoklamaya gayret buyurdu. İşbu sınıf bir yandan fenn-i cebri tahsil ve bir taraftan da Tahir Efendi'den usul-i hendeseyi tekmil edip badehu Mecmuatü'l-Mühendisin nam eseri ve ordu kurmak ve harita almak usullerini ve istihkamat-1 hafife ve cesime ve usul-i misaha fenlerini sirasiyla tedris ve talim ederlerdi. Bu sirada nazariyatı haftada iki gün ve ameliyatı her gün olmak üzere talim ameliyatı icra olunup Mösyö Santandari -muahharan ihtida edip süvari binbaşıllı̆̆ ile Bosna'ya azimet ve oralarda irtihal-i diyar-1 ahiret eylemişdir- nam muallim dahi celb ve tayin olunarak meç ve k1liç talimlerine mübaşeret edildi. 1258 tarihinde bu sınıflar gördükleri mezkur fenlerde epeyce ilerlemiş ve Arabi, Farsi dersleri hitam bulmuş olduğundan vuku bulan imtihanlarında aliyyü'l-ala olanların emsalini tergib u teşvik kasdına binaen mülazım-1 evvellik ve karibü'l-ala bulunanların mülazım-1 sanilik rütbeleriyle taltifleri tekarrür ederek balada suret-i icad ve imali beyan olunan çavuş nişanlarının şekil ve resminde fakat tekmil altından olarak mülazım-1 evvel nişanları ve onbaşı nişanlarının şekil [37] ve resminde de yine altın olarak mülazım-1 sani nişanları imal ve ihzar etdirilip yetmiş kişiden 41 efendi mülazım-1 evvel ve bakisi mülazım-1 sani nasb ve tayin buyrulup salifü'z-zikr nişanlar ita ve tahsil-i ilm ve maali edenlerin kadri ila edildi. Lakin Emin Paşa Mekteb'in bu halde gidişini pek de tahsin etmediğinden ve cennet-mekân Sultan Abdülmecid Han Hazretleri dahi ulum ve maarifin terakkisini daima arzu ve irade buyurmakda olduklarından ulüvv-i efkâr ve semuniyat-i padişahiden Emin Paşa iktibas-1 füyuzat ederek Mekteb-i Harbiye'nin tanzim u terakkisine pek büyük gayretle teşebbüs ve ibtidar eyledi.

Derhal Mekteb-i Harbiye'nin Avrupa mekteplerine tatbikan mükemmel bir mektep haline ircainı ulya-yı umur hazeratına ifade ile mektebi iki kısma bi't-tefrik birine Mekteb-i Ulum-1 Harbiye ve diğerine Mekteb-i Fünun-1 İdadiye tesmiyesiyle nizamat ve programlarının tertibi ve derslerin mikdarıyla tahsil müddetlerinin tahdidi ve iktiza eden hocaların tedariki ve bu iki mektep için lazım gelen ebniyenin inşa ve ikmali ve alat-1 hendesiye ve hikemiye ve kimyeviyenin celb u tedariki gibi bugünkü mükemmeliyetin vaz-1 esasına bezl-i tab (تاب) u ikdam eyledi.

Müşarunileyhin bu teşebbüsat-1 terakki-perveranesinin icrasına her tarafdan muavenet ve bahusus taraf-1 tammü'ş-şeref-i hümayundan her vechile ibraz-1 [38] inayet ve atıfet olunup ol vakitler ebniyesi bir katlı olarak henüz inşası hitama reside olmakda bulunan Küçük Taksim nam mahaldeki Tophane-i Amire Hastahanesi'ne -şimdiki Pankalti (Pancaldi/Pangaltı) denilen mahalldeki Mekteb-i HarbiyedirDa'ire-i Hümayun ile kütübhane ve dershane ve mütala'ahaneler ve koğuşlarla ahur ve manej ve sa'ir icab eden teferru'atın ilave ve ikmaliyle Mekteb-i Harbiye olmasına ve ol zamanlar Mekteb-i Harbiye bulunan Maçka Kışla-i Hümayunu'nun dahi mükemmelen ta'mir u tecdidiyle Mekteb-i İdadi ittihaz edilmesine karar verildi.

Binaenaleyh Maçka Kışlası'nın tahliyesi iktiza etdiğinden 1260 tarihinde Atik Dolma Bahçe Saray-1 Hümayunu'nun teferru'atından olan ve hademe ve musiki-i hümayun ve baltacılar da'irelerini muhit bulunan Çinili Köşk nam mahale Mektep kâmilen nakl etdi.

Bir taraftan Mekteb-i Harbiye ve İdadiye ittihaz olunacak olan hastahane ile Maçka Kışlası'nın tamiratına kemal-i ihtimam ile beda u mübaşeret olundu. Fakat bu teşebbüsat-1 mühimme ve bu icraat-1 hayriye-i teceddüdkârane kitaplara yazdığımız ve okuyup geçtiğimiz gibi pek de kolaylıkla hasıl 
olmayıp mevki-i icraya konulmasında ve işin yoluyla ifa olunmasında pek çok himmet ve gayret ibraz olunmuş ve bu uğurda nice emek ve meblağ sarf olunmuşdur.

İşin ibtidasında Emin Paşa'nın bu teşebbüsatı karin-i kabul buyrulduğundan padişah-1 maarif-tıynet Sultan Abdülmecid Han hazretler [39] inin irade-i seniyyeleri bi'l-istihsal Bab-1 Ali'de bir meclis-i muvakkat teşekkül edip icraat-1 mebhuseye bir kat daha vüsat ve ehemmiyet verilmişdir.

Meclis-i mezkurun azası ricalden mütercim-i evvel Fuad Efendi -sadr-1 esbak meşhur Fuad Paşa- ve sudurdan Arif Hikmet Bey -merhum şeyhülislam Arif Hikmet Bey- ve Mekteb-i Harbiye Nazırı Emin Paşa gibi hakikaten muktedir ve mütefennin zatlar idi.

Haftada iki defa inikad eden mezkur meclisin mektep hakkında verdiği karar Takvimü'l-Vakayi'de münderic olmakla ber-vech-i zir hülasaten yazıldı.

\section{Mekteb-i Askeriye Hakkında Karar}

"Evvela tevsi ve tecdid olunacak Mekteb-i Fünun-1 Harbiye'nin şakirdanı dört sınıf üzere müretteb olmak ve düvel-i mütemeddine'de olduğu gibi Devlet-i Aliyye'de dahi erkân-1 harbiye zabitanı çıkarılmak ve Harbiye'de müstakil fünun-1 cihadiye okutdurulup anın ibtidası olan ufak derslerin tedrisi için diğer askeri mektepleri -on iki yerde- açılarak anlara Mekteb-i Fünun-1 İdadiye namları verilmek ve bir İdadiye dahi Dersaadet'de açılmak ve taşra ve vilayet ordu merkezlerinde açılacak olan İdadiye [40] ordu müşirleri idaresinde bulunmak ve ümera-yı askeriye ve taşra hanedanı mahdumlarından istek edenler kaydolunmak ve fakat müstakilen hanedan ve askeri-zadelere münhasır olmayıp aslı ve nesli belli ahali evladından dahi mektebe yazılmak ve inde'n-nas bazı mezmumü'l-etvar olanlardan mektebe alınmak usullerine karar verildi. Ve müddet-i tahsiliyyesi beş sene olan İdadiye'de mikdar-1 kifaye Arabi ve Farsi ve yazı tahsil edenler bi'l-imtihan Harbiye'ye nakl olunmak ve haricde tahsil edenlerden Arabi ve Farsi'den imtihan verebilenler olur ise o misilliler İdadiye'ye alınmayıp doğrudan doğruya Harbiye'ye alınmak ve şakirdana resm-i mergub üzere elbise ve maaş ve tayinat verilmek keyfiyetleri dahi cümle mukarreratdan idi. Taşra İdadiyeleri'ne yazılıp da bi'l-imtihan Harbiye'ye nakl eden ve badehu zabit çıkan efendilerin birdenbire bilad-1 baideye sevk olunmayıp yine kendi memleketleri dâhilindeki ordulara gönderilerek efkâr-1 ahaliyi meziyet-i askeriyeye 1sındırmak hususu dahi ayrıca şart ittihaz kılındı."

Takvimü'l-Vakayi'den mehuz hülasa-i karar burada bitti. 1261 tarihinde verilen işbu karar-1 ali icab eden ordu-yı hümayun müşiranına bildirilerek ordu merkezlerinde birer bab Mekteb-i Fünun-1 İdadiye inşasına emir verildi ve bir tarafdan da Edirne, Bursa, Manastır vilayetlerine mektep tesisi için yüzbaşı ve kol [41] ağası rütbelerinde birer memur izam buyruldu.

Zamime: Bu karar-1 aliyi mütalaa eden ve saye-i padişahide zamanımızın terakkiyat-1 münevveresine matla olan zevatın karar-1 mezkuru dûn derecede görecekleri belli ise de o zamanlar istidad-1 vakte göre mezkur karar vaz olunmamış olsaydı şimdiki meşhudemiz olan terakkiyat-1 külliyeye nail olamayacağımız celi ve aşikar idi.

İşte bu vechile eslaf-1 kirama ve alelhusus Sultan Mahmud Han-1 Sani ve Abdülmecid Han-1 Gazi hazeratı gibi selatin-i izama her vechile beyan-1 şükr ve dua-yı hayr etmeye ahden ve dinen mecbur olduğumuz gibi halife-i maarif-perver Gazi Abdülhamid Han-1 Sani-yi Maali-eser efendimiz hazretlerinin dahi azm u cezm-i hümayunları tarik-i maarifi müceddidane ve eazım-pesendane bir şehrah ve efkâr-1 ammeye cevlangah olmak üzre tevsi etdiğini bir tıfl-1 nevzadın dahi inkâra mecali olmadığını maraz-1 (معرض) tahdisde arz u itirafdan kendimizi alamayız.

Maçka Kışlası'ndan Çinili Köşs'e nakl etdirilen şakirdan kema-fi's-sabık derslerine devam etmekde iken birkaç mah sonra balada Avrupa'ya izam olunduğu beyan olunan şakirdanın bazıları Dersaadet'e avdet etmiş olduklarından her birerleri devletçe ve mektepçe birer hidmet ve memuriyete nasb ve tayin olundular. [42] Ezcümle Mirliva Abdülkerim Nadir Paşa merhum henüz teşkil olunan Erkan-1 Harbiye 
sınıfı riyasetine tayin buyruldu. Üsküdarlı Ahmed Bey Erkan-1 Harbiye Mirlivalığıyla mektebe nazır-1 sani tayin olunub mektep nazırı Emin Paşa dahi yine nezaret uhdesinde kalmak üzre Dar-1 Şura-yı Askeriye aza nasb olundu. Viyana'dan avdet eden Rüstem Efendi dahi istihkâm Mirlivası ta 'yin olunup Beyoğlu Kışla-i Hümayunu'nda iki alay istihkâm teşkil edildi. Londra'dan avdet eden Selim Efendi dahi alayların birine Miralayı tayin buyruldu. Keza itmam-1 tahsil-i maarifle avdet edenlerden ve erkân-1 harbiye binbaşılarından Küçük Tahir Bey ve Ömer Fevzi Bey ve Silivrili Ali Bey ve Ramiz Bey mektebe hocalıkla nakl olundular. Muallimin-i mumaileyhimden Küçük Tahir Bey cebr-i adi, cebr-i ala, müsellesat-1 müsteviye ve küreviye, cebrin hendeseye tatbiki, mahrutiyat ve üç mihverliler yani cebrin hendeseye tatbikinin mücessemat kısmı, tamami [ve] tefazuli derslerini sirasiyla tedris etmek üzre riyaziye hocalığına ve Silivrili Ali Bey dahi coğrafya muallimliğine ve Ömer Fevzi Bey harita ve taramalar tersimiyle diğer sınıfların usul-i hendese, cebr ve hisab hocalıklarına tayin olundu. Ve zaten mektepde bulunan ve bu teşkilat miyanında uhdesine erkân-1 harbiye binbaşılı̆̆ tevcih buyrulan Büyük Tahir Efendi dahi mübtedi sınıfların hisab ve hendese [43] ve mecmuatü'l-mühendisin gibi dersleri hocalığına nasb edildi.

Bu zamanda idi ki Cebel-i Lübnan'da vuku bulan karışıklıkları teftiş ve tahkik ile icab eden 1slahat ve asayişin vaz ve teyidi ve yedlerinde bulunan eslihanın toplanması gibi hususatın icrası için Nazır-1 Mektep Emin Paşa Cebel-i Lübnan'a memur olduğu cihetle münhal olan mektep nezaretine merhum ferik Rifat Paşa tayin olundu. Merhum müşarunileyhin icmal-i ahvali nazır paşalar sırasından beyan olunmuşdur.

Rifat Paşa'nın zaman-1 nezaretinde tamir u tecdidiyle uğraşılan Mekteb-i Harbiye ve İdadiye'nin hîn-i itmamında Harbiye ve İdadiye sınıfları bi't-tefrik yeni mektebe nakillerinde hemen izaa-i evkat etdirmeyip usul-i cedide üzere derslere mübaşeret iktiza edeceğinden lazım gelen hocaların şimdiden celb u tedarikine lüzum görüldü.

\section{EK 2. Salih Zeki'nin Kamus-ı Riyaziyat'ında yer alan Emin Paşa maddesinin çevirisi (İstanbul Üniversitesi Nadir Eserler Kütüphanesi, T 910, 539-542.)}

[539] Emin (Paşa): Mekâtib-i askeriyemizde yetişen riyaziyyunun pişvası bu zat-1 ali-kadr Mühendishane-i Berri-i Hümayun müderrislerinden Hüseyin Rıfkı (bu nama müracaat oluna!) Efendi'den mündericdir. Pederi Hüseyin Rıfkı Efendi, Sultan Selim-i Salis Hazretleri’nin 1210 tarih-i hicrisinde küşad olunan Mühendishane'ye tayin buyurduğu muallimlerden ve cidden ashab-1 fazl u telifatdandır.

Emin Paşa, ibtida-yı halinde Mühendishane-i Berri-i Hümayun'a devam etmiş ve ikmal-i tahsilinde istihkâm alayına, alay emini nasb olunmuş ve görülen lüzum üzerine 1251 tarihinde Avrupa'ya izam olunan beş nefer Mühendishane ve Harbiye mezunini ve talebesi miyanında bera-yı tahsil, Londra'ya izam buyurulmuşdur.

Londra'da Cambridge Darülfünunu'nda tahsili esnasında Mühendishane'de bulunan ehass-1 rufekasina cebr ü hendese misal ve sualleri göndererek suret-i hallerini taleb eder ve talebe-i mumaileyhim tarafından yazılan cevablara, cevab olmak üzre gayet istifadeli mekatib irsal eyler idi.

Müşarunileyh, Cambridge'de tahsilini bi'l-ikmal, Dersaadet'e gelir gelmez her tarafdan nail-i ihtiram-1 fevkalade olmuş ve o vakitler böyle bir zata muhtac olan Mekteb-i Fünun-1 Harbiye Nezareti'ne tayinleri cidden muvafik-1 maslahat ve ayn-1 isabet olmuşdur:

Kabiliyetdir husul-i matlabin sermayesi

Elde istidad olunca kâr kendin gösterir

fehvasınca Emin Paşa, terakkiyat-1 fenniye hakkında menvi-i zamiri olan icraata muvaffak olmuş, millet ve devlete pek güzel hidmetler ibrazıyla bi-hakkın nail-i teveccühat-1 Veliyyü'n-niami ve haiz-i ihtiramat-1 umumi olmuşdur. 
Filhakika, memleketimizde Mekteb-i Fünun-1 Harbiye için talebe ihzarı maksad-1 alisiyle Mekatib-i İdadiye'yi tesis eden mir-i müşarunileyhdir. İşte sahib-i tercemenin teklif ve ısrarı üzerinedir ki, el-yevm Pankalti (Pancaldi/Pangaltı) denilen mahaldeki Tophane Hastahanesi, Daire-i Hümayun ile kütübhane ve dershane ve mütalaahaneler ve yatak koğuşlarıyla yemekhaneler ve ahur ve manej ve sair icab eden teferruatın ilave ve ikmaliyle, Mekteb-i Harbiye olmasına ve Maçka Kışla-i Hümayunu'nun da mükemmelen tamir ve tecdidiyle Mekteb-i İdadi ittihaz edilmesine Emin Paşa merhum delalet etmişdir.

$\mathrm{Bu}$ zat-1 gayret-simat, Mekteb-i Harbiye'ye nazır tayin buyuruldukdan biraz müddet sonra Mühendishane muallimlerinden Büyük Tahir Efendi namılla maruf bir zatı Mekteb-i Harbiye hisab ve cebir ve hendese muallimi olmak üzre celb ve tayin etdirmişdir. İşte Maçka'daki İdadi Mektebi'nde talebeye hisab-1 adi, küsur-1 aşariye, tenasüb ve logaritma, faiz hisabları ki ulum-1 riyaziyenin mukaddemat ve teferruatını tedris etdirdikden sonra, usul-i hendeseye mübaşeret etdirmişdir.

[540] Büyük Tahir Efendi ki, bilahire Erkan-1 Harb Miralayı ve Harbiye'de muallim iken vefat etmişdir. Ulum-1 riyaziyede pek ziyade mütehassıs olmadığından yukarıki sınıflarda bulunan ezkiyadan yirmi dört efendiye kendi odasında müstakilen cebir tedrisine devam etmişdir. İşte bu sınıf-1 mahsus, ilm-i cebiri Emin Paşa Hazretleri'nden ve usul-i hendeseyi de Büyük Tahir Efendi'den görerek hakiki erkân zabitanı olmak için hazırlanmış bulunuyorlar idi.

Emin Paşa Hazretleri'nin Mekteb-i Harbiye'deki nezaretleri zamanındaki icraatını Mirat-i Mekteb-i Harbiye namındaki kitaba bırakarak, biz riyazi-i şehirin terceme-i haline devam edelim: ${ }^{29}$

Müşarunileyh, 1259 sene-i hicriyesinde İngiltere'den avdetlerinde, uhdesine Mirlivalık rütbesi tevcih edilmiş ve ol vakit Şura-yı Askeri namıla mevcud olan meclis azalığı ile Mekteb-i Harbiye-i Şahane Nezareti'ne de tayin edilmiş olduğunu evvelce söylemiş idik.

1259 senesi tensikatından sonra 1261 tarihinde Şura-yı Askeri lağv edilmekle, bunun yerine kaim olmak üzre Dar-1 Şura-yı Askeri'nin teşkilinde, müşarunileyh Emin Paşa'nın kemâ-kân Mekteb-i Harbiye Nezareti uhdesinde kalmak üzre Dar-1 Şura-yı mezkur azalığına tayin ve intihab olunmuş ve o aralık Cebel-i Lübnan'da zuhur eden iğtişâşât münasebetiyle cihet-i askeriyeden me'muren oraya azimet ve ifa-yı hüsn-i hidmetle Dersaadet'e avdetinde, 1262 tarihinde uhdesine Feriklik rütbesi bi’t-tevcih, Rumeli Ordu-yı Hümayunu Riyaseti'ne tayin ve biraz sonra da Toskalık ahalisinden ve mütegallibe ve eşkiya-yı meşhureden "Köleka" ve refiki "Tafalyoz"un başlarına topladıkları yirmi bin kadar eşkiyanın tenkili için devletçe sevk olunan firak-1 askeriye kumandanları bir sene kadar uğraşıp bir netice hasıl edemediklerinden, eşkiya-yı merkumenin tedib ve terbiyesi için Arnabudluk'a (Arnavutluk) memur olmuş ve az zaman içinde muvaffakiyet-i azimeye nail olarak Köleka ve Tafalyoz'u oradan Dersaadet'e kadar kaçırmış ve eşkiya-yı bakiyeyi de dağıtmışdır ki, müşarunileyhin şu hidmeti hakikaten şayan-1 takdir ve tahsindir.

İşte bu hidmetine mükâfaten 1263 senesinde Dar-1 Şura-yı Askeri Riyaseti'ne bi't-tayin, Dersaadet'e gelmiş ve 1263 tarihinde Rütbe-i Samiye-i Müşiri ile Darb-hor Reşid Paşa'nın yerine Rumeli Ordu-y1 Hümayunu Müşirliği'ne tayin kılınmış ise de, mahall-i memuriyyetine gitmeden, görülen lüzum üzerine Şam-1 Şerif Valiliği inzimamiyle Arabistan Ordu-yı Hümayunu Müşirliği’ne tahvil-i memuriyyetle Şam-1 Şerif'e azimet etmişdir.

$\mathrm{Bu}$ zamana kadar Arabistan havalisinde "Kura-i Şeriye" icra olunmadı ̆̆ gibi birtakım uygunsuzluklar dahi la-yünkatı vuku bulmakda olduğundan, müşarunileyh, oraya vusulünde, tedabir-i saibe ve himmet-i mahsusaları eseri olarak, kan dökmeksizin cereyan eden su-i ahvali ve muamelat1, kâmilen bertaraf edildikden sonra mevak1-1 münasibeye icab-1 vech ile tayin eylediği kuvve-i askeriye sayesinde ordu-y1 mezkur dairesinde kemal-i suhuletle birinci defa olarak Kura-i Şeriye'yi icra etmişdir.

29 Salih Zeki buraya kadar olan bölümü Mirat-ı Mekteb-i Harbiye’den almıştır. 
Tekrar Şam-1 Şerif'e muvasalatında bir tarafdan ıslah-1 ahval-i mahalliye ile ve bir tarafdan da Hazret-i Şeyh-i Ekber Muhyiddin-i Arabi kuddise sirruhu'l-ali Efendimizin asar-1 celilelerinin mütalaasıyla iştigal ederek, şeyh-i müşarunileyh hazretlerinin ruhaniyet-i [541] aliyyelerinden istimdad ederek fevkalade bir suretle terakkiyat-1 maneviyyeye malik olmuşdur.

Şam'a duhulünden bir sene sonra "İrcii..."30 emrine itaatle hin-i vefatında olunan işaret üzerine, kendileri şeyh-i müşarunileyh hazretlerinin türbe-i şerifeleri dahilinde defn olunmuşdur (Rahmetullahi aleyhi ve rahmeten vasiaten).

Asarı: Sahib-i terceme Emin Paşa merhumun ele geçirilen asarından biri Mémoire sur un nouveau système de confection des fusées de guerre ünvanıla Fransızca olarak 1840 sene-i miladiyesinde Paris'de, Bachelier Matbaası'nda tab olunan risalesidir. Bu risalede mermiyata verilecek şekilden bahis olduğuna nazaran burada tekrarına lüzum görülmemişdir. Arzu eden zevat, taraf-1 aciziden Askeri Müze-i Hümayunu'na tevdi edilen nüshasını ziyaret ve mütalaa edebilirler.

“İkinci eseri, İngiltere'de muharrer Medhal-i Hisab-ı Tebeddülat $[\ldots]^{31}$ nam risale-i âliyesidir. ${ }^{32}$ Dibacesinden müsteban olduğu üzre, merhum-1 müşarunileyh, Cambridge Medresesi'nde ikmal-i tahsilinden sonra, mezkur medrese cemiyetinin azalığına kabul olunduğu sırada hem arz-1 teşekkür ve beyan-1 ihtiram hem de ilk semere-i tahsilini irae ve ilam arzusuyla risale-i mezkureyi azay1 müşarunileyhim ile kendi şeriklerine takdim olunmak üzre tertib ve tab eylemişdir. $\mathrm{Bu}$ risalenin muhteviyatının bir kısmı Hisab-ı Tebeddülat (Calcul de Variation) in ma-vudia-lehini bir suret-i vazıha ve basitada tarife müncer olmak üzre evvel-i emrde azami ve asgariye dair birkaç mes'elenin Fermat usulüyle hall ü izahından ve alelumum azami ve asgari mesailine hisab-1 tefazuli ve tamaminin suret-i tatbikiyle bu misilli mesailin bazılarının halline hisab-1 tefazulinin kâfi olmadığı ve çünki hisab-1 tefazulide mesela $(ش)=\varepsilon[y=f(x)]$ muadelesinin gösterdiği münhani ve havi olduğu mütebeddiller (mütehavviller) tagayyür ve tahavvülden masun kala ancak emsal-i tefazulilerin tayin ve manalarından bahs olunup bazı mesailde ise (نا) ش [f(x)] tâbiinin şekli dahi tahavvül etmek gibi meselenin şurutun ifa eden şekil tayin olunmak maksadıyla bir münhaniden diğer münhaniye geçilmek lüzumu tezahür edip bu vech ile hisab-1 tefazulinin fevkinde bir hisab-1 diğere ihtiyac hissetdiğini ve işte bu hisaba hisab-l tebeddülat tesmiye olunduğunu beyan ve ifadeden ibaretdir.

$\mathrm{Bu}$ risalede İngiltere müelliflerinden bahs edilmemesi, ol vakt İngilizce bu fenne dair müellefat-1 mühimme bulunmamasını müstelzimdir. Ve nihayet-i risalede, hisab-1 tebeddülata dair istihsal-i malumat-1 mufassala arzusunda olanlara Fransiz riyaziyyunundan Poisson ve Jacobi nam zatların hisab-1 tebeddülata dair layihalarının mütalaa olunmasını tavsiye ile hatm-i kelam olması da bu kavlimizi teyid eder.” (“...” arasında yazılmış olan fikarat ile atide yazılan mevadd, riyazi-i şehir Vidinli Tevfik Paşa merhumundur.) [542] "Emin Paşa merhumun Medhal-i Hisab-l Tebeddülatı yirmi yedi sahifeden az ise de, azami ve asgariye dair Fermat'nın kaide-i mahsusası hakkında malumat-1 kafiyeyi ve hisab-1 tefazuliden azami ve asgari mesailine tatbiki ile bu hisabın mesail-i mezkureyi daima halle kâfi olmadığını göstermek üzre emsile-i lazıme ve ala-tariki'l-icaz hisab-1 tebeddülatın kavaid-i amalini ve bu iki hisab beynindeki muvafakat ve mugayereti ve hisab-1 tebeddülatın tatbikatı hakkında bir fikr-i sarih ve sahih verecek derecede düsturlarını ve nihayetinde bir misal-i umumiyi şamil ve bu vech ile birkaç sahifede bir koca kitablık malumatı müştemil bulunmuşdur."

"Elhasıl, bir cemiyet-i ilmiyeye arz-1 teşekkür ü ihtiram marizinde (معرض) yazılan resailin filhakika yarım ve nihayet bir saatde okunabilecek hacim ve cesametde bulunmaları iktiza etdiğinden, medhal-i mezkurun tafsilat-1 zaideyi havi bulunmaması adab-1 fenniyeye muvafik görülmüş olmağla beraber, pek muhtasar olduğu iddia olunsa bile, merhum-1 müşarunileyhin ulum-1 riyaziye-i âliyede derece-i

30 Rabbine dön! anlamında, Kur'an-1 Kerim, Fecr Suresi, 28. ayetinin baş1.

31 Yazmada boş bırakılmış bu kısma muhtemelen kitabın İngilizce ismi yazılacaktı.

32 Salih Zeki bu kısımda verilen bilgilerin Vidinli Tevfik Paşa’ya ait olduğunu belirtmek için (“) işareti kullanmıştır. Kendisinin 541 nolu sayfanın sonundaki açıklamasına da bakılabilir. 
iktidarının tabaka-i mutadeden daha âli rütbe olduğunu isbata kâfi ve vafidir. Rahmetullahi aleyhi ve rahmeten vasiaten."

İngiltere, Fransa'dan yalnız bir boğazla ayrıldığı halde, Fransa'da Lagrange'ın icad-gerdesi olan ve Vidinli Tevfik Paşa'ya tevfikan hisab-ı tebeddülat tesmiye olunan usul-i hisaba dair en evvel İngiliz riyaziyyun ve ulemasına malumat veren zatın, Emin Beğ namındaki bir genç Türk olması ne kadar garib bir vakadır! (Salih Zeki).

Finansal Destek: Yazar bu çalışma için finansal destek almamıştır.

\section{KAYNAKÇA / BIBLIOGRAPHY}

\section{Arşiv Belgeleri / Archival Sources}

Başbakanlık Osmanlı Arşivi (BOA)

Hatt-1 Hümayun (HAT) 309/18272, 29 Mart 1253 (26 Mart 1838); Cevdet Maarif (C. MF) 43/2150, 7

Cemaziyelahir 1232 (24 Nisan 1817); İrade Dahiliye (İ. DH) 237/14320, 22 Ramazan 1267 (21 Temmuz 1851); İrade Dahiliye (İ. DH) 245/14911, 24 Safer 1268 (19 Aral1k 1851); İrade Hariciye (İ. HR) 7/352, 7 Ramazan 1256 (2 Kasım 1840); İrade Hariciye (İ. HR) 5/249, 29 Rebiülahir 1256 (30 Haziran 1840).

\section{Yazma Eserler / Manuscripts}

Salih Zeki. “Kamus-1 Riyaziyat.” İstanbul, İstanbul Üniversitesi Nadir Eserler Kütüphanesi T910.

\section{Basılı Kaynaklar / Printed Sources}

Albree, Joe, ve Scott H. Brown. "A Valuable Monument of Mathematical Genius: The Ladies' Diary (17041840).” Historia Mathematica 36, 1 (2009): 10-47.

Ameen Bey, M. Z. An Introduction to the Calculus of Variations with a Theoretical View of Maxima and Minima. Cambridge: Metcalfe and Palmer, 1839.

Aydüz, Salim. "Emin Paşa.” Yaşamları ve Yapıtlarıyla Osmanlılar Ansiklopedisi, 1:401. İstanbul: Yapı Kredi Kültür Sanat Yayınları, 2008.

Bidwell, W. H. (ed.) The Eclectic Magazine of Foreign Literature, Science, and Art. Vol. 22. New York: Leavitt, Trow, \& Co., 1851.

"British Association for the Advancement of Science". The North British Review, November 1850, 235-287 Ceride-i Havadis. 3 Zilhicce 1267.

De Morgan, Augustus. A Budget of Paradoxes. London: Longmans, Green, 1872.

De Morgan, Sophia Elizabeth. Memoir of Augustus de Morgan. London: Longmans, Green, 1882.

Emin Pacha. Mémoire sur un nouveau système de confection des fusées de guerre. Paris: Bachelier, 1840.

Farmer, Henry George. “A Turkish Officer’s Tomb at Woolwich.” Oriens 8, 1 (1955): 94-95.

Günergun, Feza. "Eski Fransız ve Osmanlı Ölçü ve Tartılarının Sistemlerindeki Eşdeğerleri: İlk Karşılaştırmalar ve Çevirme Cetvelleri." Osmanlı Bilimi Araştırmaları 2 (1998): 23-68. 
İhsanoğlu, Ekmeleddin, Ramazan Şeşen, ve Cevat İzgi. Osmanlı Matematik Literatürü Tarihi. C. 1. Editör Ekmeleddin İhsanoğlu. İstanbul: İslâm Tarih, Sanat ve Kültür Araştırma Merkezi IRCICA, 1999.

İhsanoğlu, Ekmeleddin, Ramazan Şeşen, M. Serdar Bekar, ve Gülcan Gündüz. Osmanlı Askerlik Literatürü Tarihi. C. 1. Editör Ekmeleddin İhsanoğlu. İstanbul: İslâm Tarih, Sanat ve Kültür Araştırma Merkezi IRCICA, 2004.

Mac Farlane, Charles. Turkey and its Destiny: The Results of Journeys Made in 1847 and 1848 to Examine into the State of that Country. C. 2. London: John Murray, 1850.

Mehmed Esad. Mirat-ı Mekteb-i Harbiye. İstanbul: Şirket-i Mürettibiye Matbaası, 1310.

_. Mirat-l Mühendishane-i Berr-i Hümayun. İstanbul: Karabet Matbaas1, 1312.

. Mirat-ı Mühendishane-i Berri-i Hümayun (İstanbul Teknik Üniversitesi Tarihçesi). Editör Sadık Erdem. İstanbul: İTÜ Bilim ve Teknoloji Tarihi Araştırma Merkezi, 1986.

Mehmed Süreyya. Sicill-i Osmani. C. 2. Editör Nuri Akbayar. İstanbul: Tarih Vakfı Yurt Yayınları, 1996.

Polat, Atilla. "Son Dönem Osmanlı Matematikçi-Bürokratı Vidinli Hüseyin Tevfik Paşa'nın Hayatı." Osmanlı Bilimi Araştırmaları 20,1 (2019): 16-41.

Romilly, Joseph. Romilly's Cambridge Diary, 1832-1842. Cambridge: Cambridge University Press, 1967.

Takvim-i Vakayi. 27 Zilhicce 1267.

The Cambridge Chronicle and Journal, and Huntingdoneshire Gazette. 12 Aralik 1840.

The Ladies' Diary. London: The Company of Stationers, 1839.

The Ladies' Diary. London: The Company of Stationers, 1840.

The Lady's and Gentleman's Diary. London: The Company of Stationers, 1841.

Venn, John, ve John Archibald Venn (editors). Alumni Cantabrigienses: A Biographical List of All Known Students Graduates and Holders of Office at the University of Cambridge, From the Earliest Times to 1900. Volume 2: From 1752 to 1900, Part 1: Abbey-Challis. C. 2. Cambridge University Press, 2011.

\section{Tezler / Dissertations}

Dönmez, Ahmet. “Osmanlı-İngiliz İlişkileri: Diplomasi ve Reform (1833-1841).” Yayımlanmamış Doktora Tezi, Selçuk Üniversitesi, 2013.

\section{Elektronik Kaynaklar / Electronic Sources}

“The Jargon.” Erişim 05 Mart 2019. http:/www.queens.cam.ac.uk/life-at-queens/about-the-college/ university/the-jargon

“Cambridge Üniversitesi Mezun Arama Sayfası”. Erişim 05 Mart 2019. http://venn.lib.cam.ac.uk/cgi$\mathrm{bin} / \mathrm{search}-2018$.pl? $\mathrm{sur}=\&$ suro $=\mathrm{w} \&$ fir $=\&$ firo $=\mathrm{c} \& \mathrm{cit}=\& \mathrm{cito}=\mathrm{c} \& \mathrm{c}=\mathrm{all} \& \mathrm{z}=\mathrm{all} \& \mathrm{tex}=\mathrm{ameen} \& \mathrm{sye}=\&$ eye $=1839 \& \mathrm{col}=\mathrm{all} \& \operatorname{maxcount}=50$

“Emin Paşa’nın matematik kitabının St. John’s Koleji Kütüphanesi’ndeki kopyası”. Erişim 05 Mart 2019. http://idiscover.lib.cam.ac.uk/primo-explore/fulldisplay?docid=44CAM_ALMA21417766960003606 \&context=L\&vid=44CAM_PROD\&search_scope=default_scope\&tab=default_tab\&lang $=$ en_US

“Emin Paşa’nın matematik kitabının Trinity Koleji Kütüphanesi’ndeki kopyası”. Erişim 05 Mart 2019. http:// idiscover.lib.cam.ac.uk/primo-explore/fulldisplay?docid=44CAM_CON5351115212\& context=L\&vid= 44CAM_PROD\&search_scope=default_scope\&tab=default_tab\&lang=en_US 
